\title{
DEVELOPMENT OF ENZYME-LINKAGE IMMUNOSORBENT ASSAY AGAINST TYPE B OF CLOSTRIDIUM BOTULINUM: A PRELIMINARY STUDY
}

\author{
S. N. Depamede and D. Kisworo \\ Faculty of Animal Science, Mataram University, \\ Jl. Majapahit No. 62 Mataram NTB 83125 - Indonesia \\ Corresponding E-mail: sulaiman_n@unram.ac.id
}

Received October 06, 2011; Accepted Nopember 15, 2011

\begin{abstract}
ABSTRAK
Neurotoksin Clostridium botulinum (BoNTs) merupakan salah satu penyebab kerugian ekonomi bagi industri peternakan. Kerugian ini dapat sebagai akibat langsung ketika ternak keracunan BoNTs atau secara tidak langsung ketika produk asal ternak terkontaminasi BoNTs sehingga produk tersebut dilarang untuk dipasarkan. Untuk itu perlu dilakukan pengontrolan rutin penyebaran BoNTs di lingkungan peternakan dan industri hasil ternak. Salah satu caranya adalah dengan melakukan deteksi rutin terhadap keberadaan BoNTs. Salah satu metode deteksi yang relatif cepat dan akurat adalah metode enzyme linkage immunosorbant assay (ELISA). Pada penelitian ini dilaporkan hasil pengembangan ELISA, menggunakan antibodi poliklonal produk lokal terhadap BoNTs-B. Antibodi dihasilkan dari enam mencit Balb/c dengan metode imunologi standar. Mencit diimunisasi 3 kali selama 8 minggu dengan toksoid C. Botulinum tipe B komersial dengan dosis $100 \mathrm{ng}$ per ekor per injeksi. Antibodi yang dihasilkan dimurnikan dengan kombinasi metode presipitasi ammonium sulfat 50\% (w/v) dan kolom protein A. Hasil studi pendahuluan ini menunjukkan bahwa metode ELISA yang dikembangkan mampu mendeteksi toksin Clostridium botulinum tipe B hingga 1,0 ng/ml.

Kata kunci: toksin C. botulinum, ELISA, antibodi poliklonal
\end{abstract}

\begin{abstract}
Clostridium botulinum neurotoxin (BoNTs) is one of the causes of economic loss in the livestock industry. This economic loss would be as a direct result when animals poisoned by BoNTs or indirectly when the livestock products are contaminated by BoNTs, which end up with the products are banned by authority. Therefore a routine surveillance of BoNTs in the farm and in livestock product processing industry is urgently needed. One of the most relatively quick and accurate methods to perform a routine detection of the presence of BoNTs is enzyme-linkage immunosorbant assay (ELISA). In this article we describe the results of the development of ELISA, using polyclonal antibodies against BoNTs-B produced locally. Antibodies were generated from six Balb/c mice with standard immunological methods. Mice were immunized three times for a period of 8 weeks with a commercial type B Clostridium botulinum toxoid at a dose of $100 \mathrm{ng}$ per mouse per injection. The resulting antibody was purified by a combination of ammonium sulfate precipitation $50 \%(\mathrm{w} / \mathrm{v})$ technique and a protein A column method. The results of this preliminary study indicated that the developed ELISA method capable of detecting type B Clostridium botulinum toxin up to $1.0 \mathrm{ng} / \mathrm{ml}$.

Keywords: C. botulinum toxin, ELISA, polyclonal antibody.
\end{abstract}

\section{INTRODUCTION}

Clostridium botulinum neurotoxin (BoNTs) is the causative agent of botulism, a fatal disease characterized by muscular paralysis, which affect mammals, birds, and fish (Keto-Timonen et al., 2005, Steinman et al., 2006). Livestock botulism is a worldwide problem that causes large economic losses (Steinman et al., 2006). The losses that incurred on the farm industry can be happened directly or indirectly. The direct loss occurred when the animal is attacked directly, such as when they ingest $C$. botulinum spores contaminated feed. Indirect losses arose if the spores are found in animal processed products such as sausages or burgers (Shapiro et al., 1998), 
even in honey (Nevas et al., 2002), which in turn causes the products are no longer economically valuable even banned by the authority. To overcome the problems early prevention is needed. This can be done by both routine handling of the livestock sanitary as well as maintaining the hygiene of processing livestock products. In addition routine screening tests again BoNTs are required.

Commonly test method performed is mouse bioassay, which measures the resistance of mice to the toxin (Witcome et al., 1999; Gessler et al., 2005). The assay is able to detect up to one unit dose of one mouse lethal dose (1 MLD), which is equivalent to approximately $10 \mathrm{pg} / \mathrm{ml}$ of neurotoxins (Sharma et al., 2005). Hence, this method is categorized quite sensitive. However, the operational cost of this method is relatively high due to the need of mice with specific conditions. Furthermore it takes special skills, animal ethics concerns, as well as the specificity of neurotoxins detected is still very limited. It also needs quite long time to get results, which is about 4 days or more (Sharma et al., 2005). Consequently several methods have been developed ranging from ELISA (Dezfulian et al., 1984; Witcome et al., 1999), immunoaffinity chromatographic column test (Gessler et al., 2005), fluorogenic assay (Anne et al., 2001), up to the bio-molecular test such as PCR (Fach et al., 1995; Braconnier et al., 2001; Kimura et al., 2001; Lindstrom et al., 2001; Fach et al., 2002).

The advantages of the ELISA method are faster than the mouse bioassay method, sensitive with high specificity, easy to standardize, and is commonly performed even to the level of public health laboratories (Sotelo et al., 2011). In the present study it was attempted to develop an ELISA method to the $C$. botulinum toxin using the antibody which was developed locally. The results should provide a better understanding of the development of the method as well as to carry out an early protection against the spreading of $C$. botulinum in the farm and animal industries.

\section{MATERIALS AND METHODS}

\section{Polyclonal Antibody Production}

Polyclonal antibodies used in this study were generating locally by Depamede and Kisworo (2009). Polyclonal antibodies were produced in mice based on Dixit et al., (2006) and Keller et al., (2008) with some modifications as mentioned by Depamede and Kisworo (2009). Six female
Balb/c mice aged 6-8 weeks were immunized with a commercial type B $C$. botulinum toxoid (Lot No. B121908-01, Metabiologics, Inc., U.S). Mice were immunized 3 times for 8 weeks with a dose of $100 \mathrm{ng}$ per mouse with 4 weeks interval. In the initial immunization, toxoid was mixed with complete Freund's adjuvant (CFA, Sigma) to form an emulsion. On the second immunization a mixture with incomplete Freund's adjuvant (ICFA, Sigma) was performed. The first and the second injection were carried out subcutaneously, while the third injection (at week 8) was administered intramuscularly. As a control, Balb/c mice were injected concurrently with the treatments but the toxoid was replaced with physiological saline solution. Fourteen days after final immunization, serum of each treatment group and control was taken from the mouse tail. The serum was then frozen at $-20^{\circ} \mathrm{C}$ until processed for purification.

\section{Isolation and Purification of Polyclonal Antibodies}

Isolation and purification of polyclonal antibodies against BoNTs-B toxin generated from $\mathrm{Balb} / \mathrm{c}$ mice was carried out by $50 \%$ (w/v) ammonium sulfate precipitation and Protein A column methods (Baumgarten, 1992). The purity of the antibody was analyzed using sodium dodecyl sulfate polyacrylamide gel electrophoresis (SDS-PAGE) according to Hempelmann (1992).

\section{Development of ELISA}

The isolated antibodies and a commercial antibody (Abcam) were used to develop sandwich ELISA according to Farzamfar et al. (2007) with slight modification as performed by Depamede and Kisworo (2009). ELISA plates were firstly coated with rabbit anti type $\mathrm{B}(\mathrm{RaCB}) C$. botulinum toxin commercial (Abcam) as the first antibody layer. Each well was coated with $100 \mu \mathrm{L}$ (2 $\mu \mathrm{g} / \mathrm{ml}$ ) antibody in carbonate buffer solution $\mathrm{pH} 9.5$ and then allowed to stand at $4^{\circ} \mathrm{C}$ for 12 hours. After that the solution was discarded, replaced with $300 \mu \mathrm{L}$ blocking solution (PBS containing $0.05 \%$ (v/v) Tween 20 (Sigma), and $0.5 \%(\mathrm{w} / \mathrm{v})$ bovine serum albumin) and allowed to stand for 60 minutes at room temperature. The plates were then washed five times with 300 $\mu \mathrm{L} /$ well of washing solution (PBS containing $0.05 \%$ (v/v) Tween 20). After washing, the wells were filled with $50 \mu \mathrm{L} /$ well of standard commercial ELISA for $C$. botulinum toxin (Metabiologics, Inc.) with a concentration of 100 
$\mathrm{ng}, 1 \mathrm{ng}, 0,2 \mathrm{ng}, 0.1 \mathrm{ng}$, and $0 \mathrm{ng} / \mathrm{ml}$, and incubated for $60 \mathrm{~min}$ at room temperature. Then the plate was washed again 5 times and then 50 $\mu \mathrm{L}$ of polyclonal antibody generated in this study as the second layer, concurrently with the controls was added in to the wells and incubated for 60 minutes at room temperature. The purpose of these second layer antibodies are as a linker between suspected antigen (BoNTs) in the samples and the enzyme Horseradish peroxidase(HRP)-conjugated antibody. After washing, $50 \mu \mathrm{L}$ goat-anti-mouse IgG HRPconjugated antibodies were dropped into the ELISA plate wells and incubated again for another 60 minutes at room temperature. After the last wash, a $50 \mu \mathrm{L}$ substrate was added to the wells and incubated for 5-10 minutes in the dark, at room temperature until the reaction color changes in the positive samples occurred. The reaction was stopped by adding $50 \mu \mathrm{L}$ of $1 \mathrm{~N}$ $\mathrm{H}_{2} \mathrm{SO}_{4}$ then the reaction products were quantified by ELISA photo reader (DYNEX-MRX) on the optical density of $450 \mathrm{~nm}$ (OD 450).

\section{Data Analysis}

The data obtained were tabulated and analyzed by a simple arithmetic mean (Mean \pm SD) of the OD 450 (Drouet et al., 2003) and presented as reported by Depamede and Kisworo (2009). The calculation of the limit value of positive or negative test results (cut-off value, COV) is calculated based on Drouet et al. (2003), ie, $\mathrm{COV}=$ average value of negative controls \pm 3 $x$ SD of negative control value. Samples with a $\mathrm{COV} \leq \mathrm{OD} 450$ value was designated negative, while a greater than $\mathrm{COV}$ was positive (Depamede and Kisworo, 2009).

\section{RESULTS AND DISCUSSION}

Of the six Balb/c mice used, one animal died during the study due to unknown reasons, but certainly not as a result of vaccination. Of the 5 mice leaved, $4(80 \%)$ gave a positive immune response or produced polyclonal antibodies against type B C. botulinum toxin, and one of them gave a quite high immune response, while one was with the lowest immune response (+/-) as presented in Table 1.

From these results it appears that the immune response of Balb/c mice was individually quite disperse (variation value was about $47.63 \%$ ), and only one mouse gave high enough immune response. These results were consistent with previous studies, especially when the vaccine or immunogen used was a commercial immunogen; native immunogen reported to be more immunogenic than those of the commercial toxoid (Witcome et al., 1999; Keller, 2008). In the present study, immunogen used was a commercial C. botulinum toxoid. Technically, the use of commercial immunogen is more secure than the intact or native immunogen derived or isolated directly from $C$. botulinum.

Furthermore, from the results of this study as reported also by Depamede and Kisworo (2009), it was noted also that the dose of $100 \mathrm{ng} / \mathrm{ml}$ gave a significant immune response $(\mathrm{p}<0.05)$ on the production of polyclonal antibodies (Figure 1). Polyclonal antibodies obtained were then purified by ammonium sulfate precipitation method and the protein A 'home made mini-column'. The results of purification were analyzed using SDSPAGE as shown in Figure 1. From this figure, it clear knwn that the antibody obtained was quite pure.

Polyclonal antibody obtained was then used as a component of the development of indirect ELISA as mentioned in the mateials and methods or as explained elsewhere by Depamede and Kisworo (2009). Preliminary results of the developed ELISA method in this study showed

Table 1. Immune Response of Balb/c mice Against C. botulinum Toxoid

\begin{tabular}{ccc}
\hline Balb/c Code & $\begin{array}{c}\text { The mean value } \\
\mathrm{OD}_{450}(\mathrm{n}=3)\end{array}$ & $\begin{array}{c}\text { Immune Response } \\
(\mathrm{COV}=0.350)\end{array}$ \\
\hline 1 & 0.580 & + \\
2 & 1.156 & +++ \\
3 & $\dagger)$ & $\dagger)$ \\
4 & 0.423 & +- \\
5 & 0.500 & + \\
6 & 0.642 & + \\
\hline
\end{tabular}

$\dagger)$ Mouse died during the study

(Source: Depamede and Kisworo, 2009). 
(a)

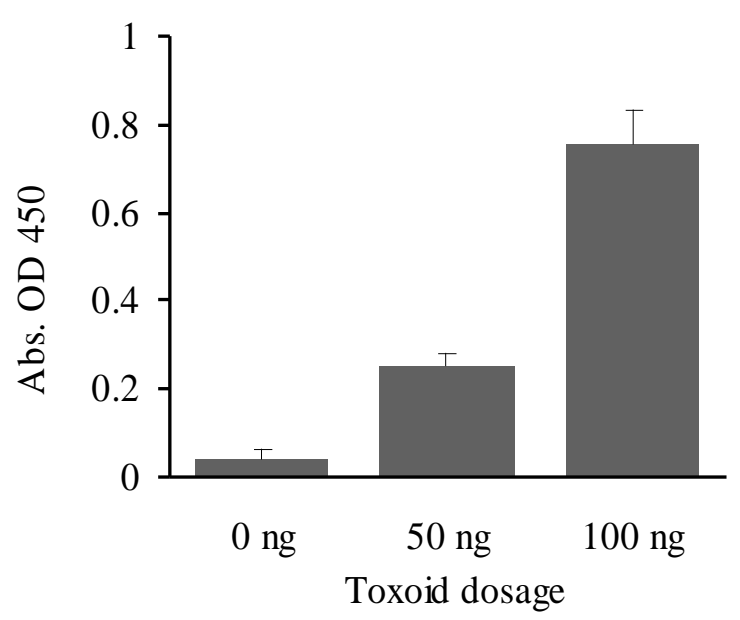

(b)

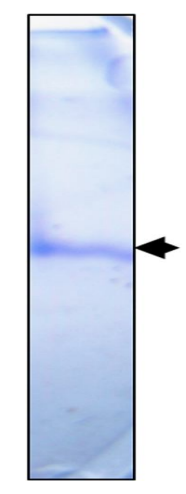

Figure 1. Effects of a Commercial C. botulinum Toxoid Vaccine Dosages on Production of Polyclonal Antibodies of Local Balb/c Mice (a) and a Representative Result of 12.5\% SDS-PAGE Analysis of Polyclonal Antibodies (arrow) Purified by Protein A Column (b).

that polyclonal antibodies generated in this study can be used as a component of ingredients needed to develop immunoassay such as ELISA against C. botulinum toxin. Figure 2 shows that the developed ELISA was able to detect type B $C$. botulinum toxin up to a concentration of 1.0 $\mathrm{ng} / \mathrm{ml}$.

When compared to the in vivo mouse bioassay test, the results of this preliminary study were yet as sensitive as the bio-assay method. Bio-assay method was able to detect the toxin of C. botulinum from 0.01 up to $0.02 \mathrm{ng}$ (Witcome $e t$ al., 1999). Although the bio-assay method is more sensitive, as mentioned elsewhere, the method requires animals with special handling, special skills, and time consume. Furthermore, there is a consideration of restrictions on the use of trial animals that increasingly constricted in the last few decades (Witcome et al., 1999). These considerations have led the researchers to develop a more practical method of testing by applying the principles of immunodiagnostics such as ELISA.

Lee et al. (2005), Atassi (2006), and Keller (2008) suggested that if immunodiagnostics need to be developed, it would be better if using antibodies produced from modified $C$. botulinumintact toxin. They found that "home-made vaccine" from native $C$. botulinum antigens were more immunogenic and more protective than those of commercial antigens (Keller, 2008). Furthermore, Witcome et al. (1999) has

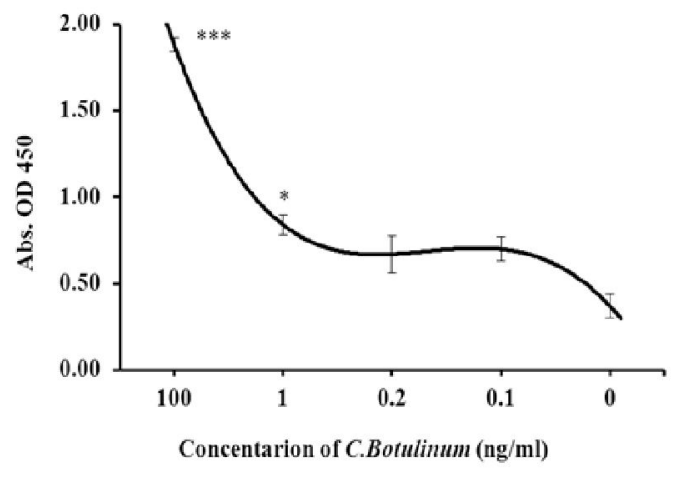

Figure 2. The Results of the Detection of a Commercial C. botulinum toxoid (BoNT) using the ELISA Developed in this Study. Toxin was Detected up to $1 \mathrm{ng} / \mathrm{ml}$. ** $\mathrm{P}<0.001 ; * \mathrm{P}<0.05$ Compared to Control $(0 \mathrm{ng} / \mathrm{ml}, \mathbf{n}=3)$.

successfully developed a modified ELISA test using monoclonal antibodies produced from the modified native $C$. botulinum antigens. It was claimed that the modified ELISA was able to detect the $C$. botulinum toxin up to $0.005 \mathrm{ng}$, or in other words two times more sensitive than the bio-assay method, which was able to detect 0.01 ng (Witcome et al., 1999). From this account, it can be revealed here that the quality of the antibodies obtained in this preliminary study to be used as component for the development of ELISA 
can still be improved further.

\section{CONCLUSIONS}

An ELISA kit for detecting C. botulinum toxins has been developed by applying polyclonal antibodies against $C$. botulinum generated locally in this preliminary study.

\section{ACKNOWLEDGMENTS}

The research was funded by DP2M-Higher Education through the National Strategic Research Grant to Mataram University for the 2009 fiscal year of Grant No. 0234.0/023$04.2 / \mathrm{XXI} / 2009$. The authors wish to thank Mr. Khalid, S.Si and Ms. I.G. Ayu Andayani, S.Si., staffs at the Immunobiology Laboratory of Faculty of Mathematics and Natural Sciences, Mataram University, for their technical assistances.

\section{REFERENCES}

Anne, C., F. Cornille, C. Lenoir, and B. P. Roques. 2001. High-throughput fluorogenic assay for determination of botulinum type B neurotoxin protease activity. Anal. Biochem. 291:253261.

Atassi, M.Z. 2006. On the enhancement of antineurotoxin antibody production by subcomponents HA1 and HA3b of Clostridium botulinum type B $16 \mathrm{~S}$ toxinhaemagglutinin. Microbiol. 152: 1891-1895.

Baumgarten, H. 1992. Protein A/Protein G Column Chromatography. In: Peters, J.H. and Baumgarten, H. (Eds.). Monclonal Antibodies. Springer -Verlag. Berlin. pp 264271.

Braconnier, A., V. Broussolle, S. Perelle, P. Fach, C. NguyenThe, and F. Carlin. 2001. Screening for Clostridium botulinum type A, $\mathrm{B}$, and $\mathrm{E}$ in cooked chilled foods containing vegetables and raw material using polymerase chain reaction and molecular probes. J. Food Prot. 64:201-207.

Depamede, S.N and D. Kisworo. 2009. Generating of Polyclonal Antibodies for Detection of Type B Clostridium botulinum toxin: A Preliminary Study on the Development of Immunodiagnostics against C. botulinum. Proceedings, National Seminar and Exhibition of Research Outcomes $\left(47^{\text {th }}\right.$ Anniversary of UNRAM), Research Institute of Mataram University, Mataram, Lombok, Indonesia, September 29 - 30, 2009. B4. pp. 1-9.

Dezfulian, M., C. L. Hatheway, R. H. Yolken, and J. G. Bartlett. 1984. Enzyme-linked immunosorbent assay for detection of Clostridium botulinum type A and type B toxins in stool samples of infants with botulism. J. Clin. Microbiol. 20:379-383.

Dixit, A., S.I. Alam, R.K. Dhaked, and L. Singh. 2006. Development of an immunodetection test for a botulinum-likeneurotoxin produced by Clostridium sp. RKD. Indian J. Med. Res. 124:355-362.

Drouet, C., M-F. Nissou, D. Ponard, J. Arvieux, C. Dumestre-Perard, P. Gaudin, B. Imbert, C. Massot, and F. Sarrot-Reynauld. 2003. Detection of Antiendothelial Cell Antibodies by an Enzyme-Linked Immunosorbent Assay Using Antigens from Cell Lysate: Minimal Interference with Antinuclear Antibodies and Rheumatoid Factors. Clin. Diagn. Lab. Immunol. 10: 934-939.

Fach, P., M. Gibert, R. Griffais, J. P. Guillou, and M. R. Popoff. 1995. PCR and gene probe identification of botulinum neurotoxin A-, B-, E-, F-, and G-producing Clostridium spp. and evaluation in food samples. Appl. Environ.Microbiol. 61:389-392.

Fach, P., S. Perelle, F. Dilasser, J. Grout, C. Dargaignaratz, L. Botella, J-M. Gourreau, F. Carlin, M. R. Popoff, and V. Broussolle. 2002. Detection by PCR-Enzyme-Linked Immunosorbent Assay of Clostridium botulinum in Fish and Environmental Samples from a Coastal Area in Northern France. Appl. Environ.Microbiol. 68:58705876.

Farzamfar, B., S. Bayanolhagh, F. Mahboudi, and M. Zahrai. 2007. The Effect of Different Stabilizers on Stability of Horseradish Peroxidase- Bovine Serum AlbuminAflatoxin B1, a Conjugated Tracer for Detection of Aflatoxin B1 in ImmunoassayBased Methods. Iranian J. Phramceut. Res. 6 (3): 179-184.

Gessler, F., K. Hampe, and H. Bohnel. 2005. Sensitive detection of botulinum neurotoxin types $\mathrm{C}$ and $\mathrm{D}$ with an immunoaffinity chromatographic column test. Appl. Environ. Microbiol. 71:7897-7903.

Hempelmann, E. 1992. Analytical SDS Polyacrylamide Gel Electrophoresis (SDSPAGE). In: Peters, J.H. and Baumgarten, H. 
(Eds.). Monclonal Antibodies. Springer Verlag. Berlin. pp 430-434.

Keller, J. E. 2008. Characterization of new formalin-detoxified Botulinum neurotoxin toxoids. Clin. Vac. Immunol. 15: 1374-1379.

Keto-Timonen, R., M. Nevas, and H. Korkeala. 2005. Efficient DNA fingerprinting of Clostridium botulinum types A, B, E, and F by Amplified Fragment Length Polymorphism Analysis. Appl. Environ. Microbiol. 71(3):1148-1154.

Kimura, B., S. Kawasaki, H. Nakano, and T. Fujii. 2001. Rapid, quantitative PCR monitoring of growth of Clostridium botulinum type $\mathrm{E}$ in modified atmosphere-packaged fish. Appl. Environ. Microbiol. 67:206-216.

Lee, J-C., K. Yokota, H. Arimitsu, H-J. Hwang, Y. Sakaguchi, J. Cui, K. Takeshi, T. Watanabe, T. Ohyama and K. Oguma. 2005. Production of anti-neurotoxin antibody is enhanced by two subcomponents, HA1 and HA3b, of Clostridium botulinum type B $16 \mathrm{~S}$ toxinhaemagglutinin. Microbiol. 151: 3739-3747.

Lindstrom, M., R. Keto, A. Markkula, M. Nevas, S. Hielm, and H. Korkeala. 2001. Multiplex PCR assay for detection and identification of Clostridium botulinum types A, B, E and F in food and fecal material. Appl. Environ. Microbiol. 67:5694-5699.

Nevas, M., S. Hielm, M. Lindström, H. Horn, K. Koivulehto, and H. Korkeala. 2002. High prevalence of Clostridium botulinum types A and $\mathrm{B}$ in honey samples detected by polymerase chain reaction. Int. J. Food Microbiol. 72(1-2):45-52.
Shapiro, R.L., C. Hatheway, D.L. And Swerdlow. 1998. Botulism in the United States: a clinical and epidemiologic review. Ann. Intern. Med. 129 (3): 221-228.

Sharma, S.K., B.S. Eblen, R.L. Bull, D.H. Burr, and R.C. Whiting. 2005. Evaluation of Lateral-Flow Clostridium botulinum Neurotoxin Detection Kits for Food Analysis. Appl. Environ.Microbiol. 71: 3935-3941.

Sotelo, E., F. Llorente, B. Rebello, A. Camunas, A. Venteo, C. Gallardo, A. Lubisi, M.J. Rodriguez, A.J. Sanz, J. Figuerola and M.A. Jimenez-Clavero. 2011. Development and evaluation of a new epitope-blocking ELISA for universal detection of antibodies to West Nile virus. J. Virol. Methods 174: 35-41.

Steinman, A., M. Chaffer, D. Elad, and N. Y. Shpigel. 2006. Quantitative Analysis of Levels of Serum Immunoglobulin $G$ against Botulinum Neurotoxin Type D and Association with Protection in Natural Outbreaks of Cattle Botulism. Clin. Vaccine Immunol. 13 (8): 862-868.

WHO. 2002. Clostridium Botulinum. International Programme on Chemical Safety Poisons Information Monograph 858 Bacteria. World Health Organization. Erfurt, Germany.

Witcome, M., K. Newton, K. Jameson, B. Hallis, P. Dunnigan, E. Mackay, S. Clarke, R. Taylor, J. Gaze, K. Foster, and C. Shone. 1999. Development of an In Vitro Bioassay for Clostridium botulinum Type B Neurotoxin in Foods That Is More Sensitive than the Mouse Bioassay. Appl. Environ. Microbiol. 65: 3787-3792. 